\title{
KEMAMPUAN MENULIS IKLAN PENAWARAN SISWA KELAS VIII SMP NEGERI 1 LAWA
}

\author{
Wa Asri ${ }^{1}$, Sri Suryana Dinar ${ }^{2}$, \\ Pbsi.fkip.uho@gmail.com
}

1,2 Jurusan Pendidikan Bahasa dan Sastra Indonesia

Fakultas Keguruan dan Ilmu Pendidikan, Unversitas Halu Oleo

Kampus Hijau Bumi Tridharma Andounohu, Kendari, Indonesia

\begin{abstract}
ABSTRAK
Penelitian ini bertujuan untuk mendeskripsikan kemampuan menulis iklan penawaran siswa kelas VIII SMP Negeri 1 Lawa. Jenis penelitian ini adalah penelitian kelas karena peneliti terlibat langsung di SMP Negeri 1 Lawa khususnya kelas VIII sebagai tempat untuk memperoleh data penelitian. Metode yang digunakan dalam penelitian ini adalah metode deskriptif kuantitatif yaitu menyajikan data-data yang ditemukan di lapangan yang berhubungan dengan kemampuan menulis iklan penawaran siswa kelas VIII SMP Negeri 1 Lawa yang selanjutnya diuraikan menggunakan angka-angka dengan prinsip statistik. Populasi dalam penelitian adalah keseluruhan siswa kelas VIII SMP Negeri 1 Lawa tahun ajaran 2019/2020. Populasi tersebut terbagi dalam lima kelas, maka penarikan sampel dalam penelitian ini adalah 105 dari jumlah populasi 144 siswa. Instrumen yang digunakan dalam penelitian ini adalah tes kemampuan menulis. Hasil penelitian menunjukan bahwa secara individual terdapat $58(55,23 \%)$ siswa masuk kategori mampu dan $47(44,76 \%)$ siswa dikategorikan tidak mampu. Secara klasikal persentase kemampuan siswa dikategorikan tidak mampu karena belum mencapai kriteria ketuntasan klasikal $85 \%$.
\end{abstract}

Kata Kunci: kemampuan; menulis; iklan penawaran 


\begin{abstract}
This study aims to describe the ability to write a bid ad for eighth grade students of SMP Negeri 1 Lawa. This type of research is classroom research because researchers are directly involved in SMP Neger 1 Lawa espencially in class VIII as a place to obtain research data. The method used in this study is a quantitative descriptive method that presents data found in the field relating to the ability to write a bid advertisement for eighth grade students of SMP Negeri 1 Lawa, which is then described using numbers with statistical principles. The population in this study were all eighth grade students of SMP Negeri 1 Lawa in the 2019/2020 school year. The population is divided into five classes, so the sample collection in this study was 105 from a total population of 144 students. The instrument used in this study was a test of writing ability. The results showed that individually there were $58(55,23 \%)$ students included in the category of able and $47(44,76 \%)$ studests were categorized as unable because they had not yet reached the $85 \%$ completeness criteria.
\end{abstract}

Keywords: ability; writing; advertising offer 


\section{Pendahuluan}

Pembelajaran bahasa Indonesia meliputi empat aspek keterampilan berbahasa, yaitu menyimak, berbicara, membaca, dan menulis. Keempat keterampilan tersebut masing-masing memiliki fungsi yang berbeda. Untuk komunikasi secara lisan orang menggunakan keterampilan menyimak dan berbicara, sedangkan dalam komunikasi tertulis orang memanfaatkan keterampilan membaca dan menulis.

Menulis termasuk suatu keterampilan yang harus dikuasai siswa pada pembelajaran Bahasa Indonesia, yakni keterampilan berbahasa secara produktif yang digunakan secara tidak langsung, tidak secara tatap muka dengan orang lain, maka proses pembelajaran bahasa Indonesia dituntut pula kesempatan bagi siswa untuk berlatih menulis. Semakin sering siswa diberi kesempatan berlatih menulis, tentulah mereka akan semakin terampil dalam menulis.

Peneliti melakukan penelitian mengenai keterampilan menulis karena pada kenyataannya masih banyak siswa yang merasa kesulitan menyelesaikan tugas menulis yang diberikan oleh guru bahasa Indonesia. Kegiatan menulis juga masih kurang diminati oleh siswa karena mereka merasa sulit untuk menuangkan ide-ide ke dalam sebuah tulisan. Pada pembelajaran bahasa Indonesia khususnya menggunakan keterampilan menulis, para siswa haruslah diberi kesempatan secara luas untuk mengembangkan aktivitas dan kreativitasnya agar siswa terampil menulis.

Berdasarkan kurikulum 2013 mata pelajaran Bahasa Indonesia pada umumnya berbasis teks. Materi yang terdapat dalam mata pelajaran bahasa Indonesia khususnya kelas VIII SMP adalah teks berita, teks iklan, slogan, poster, teks eksposisi, teks eksplanasi, teks ulasan, dan teks persuasi. Pada penelitian ini terfokus pada materi iklan. Materi tentang iklan tercantum dalam silabus mata pelajaran Bahasa Indonesia kelas VIII SMP dengan kompetensi dasar 3.4 Menelaah pola penyajian dan kebahasaan teks iklan, slogan atau poster (yang membuat bangga dan memotivasi) dari berbagai sumber yang dibaca dan didengar dan kompetensi dasar 4.4 Menyajikan gagasan, pesan dan ajakan dalam bentuk iklan, slogan, atau poster secara lisan dan tulis. Setelah mempelajari kaidah kebahasaan teks iklan, siswa dinyatakan menguasai materi jika mampu mencapai kompetensi dasar menyajikan gagasan, pesan, dan ajakan dalam bentuk iklan, slogan, atau poster secara lisan dan tulis. Dalam hal ini, peneliti ingin mengetahui sejauh mana kemampuan siswa saat menulis iklan.

Penelitian ini memfokuskan pada satu jenis iklan saja, yakni iklan penawaran. Jika semua jenis iklan dijadikan fokus penelitian, maka aspek penilaiannya juga berbeda-beda.

Sebagai tempat penelitian dilakukan di SMP Negeri 1 Lawa di Kabupaten Muna Barat. Pemilihan sekolah tersebut didasari pertimbangan bahwa SMP Negeri 1 Lawa adalah salah satu sekolah yang sudah menerapkan kurikulum 2013 dan belum pernah dilakukan penelitian tentang menulis iklan.

Berdasarkan observasi awal dengan guru mata pelajaran Bahasa Indonesia SMP Negeri 1 Lawa memberikan gambaran bahwa materi iklan adalah salah satu materi yang telah diajarkan di sekolah pada siswa kelas VIII di semester ganjil. Namun, ada pertanyaan apakah dengan selesainya mempelajari materi iklan ini siswa akan mampu menulis iklan penawaran berdasarkan unsur-unsur iklan dengan baik dan benar. Oleh karena itu, peneliti ingin mengetahui seberapa jauh kemampuan siswa dalam pembelajaran Bahasa Indonesia khususnya pada materi kemampuan menulis iklan penawaran siswa kelas VIII SMP Negeri 1 Lawa.

Berdasarkan latar belakang yang telah diuraikan sebelumnya, maka yang menjadi masalah dalam penelitian ini yaitu apakah siswa kelas VIII SMP Negeri 1 Lawa sudah mampu menulis iklan penawaran?

Tujuan yang ingin dicapai dalam penelitian ini yaitu untuk mendeskripsikan kemampuan menulis iklan penawaran siswa kelas VIII SMP Negeri 1 Lawa.

Hasil penelitian ini diharapkan dapat memberikan manfaat sebagai berikut:

1. Sebagai bahan informasi bagi guru bahasa Indonesia khususnya SMP Negeri 1 Lawa tentang kemampuan siswa dalam menulis iklan penawaran.

2. Sebagai upaya dan pembinaan bagi sekolah yang diteliti dalam rangka 
peningkatan mutu pembelajaran Bahasa dan Sastra Indonesia khususnya menulis iklan penawaran.

3. Salah satu upaya membangun kreatifitas siswa dalam menulis iklan penawaran.

4. Sebagai masukkan bagi peneliti dalam memperkaya wawasan mengenai pembelajaran menulis iklan penawaran.

Menulis merupakan suatu kegiatan komunikasi berupa penyampaian pesan (informasi) secara tertulis kepada pihak lain dengan menggunakan bahasa tulis sebagai alat atau medianya. Aktivitas menulis melibatkan beberapa unsur, yaitu: penulis sebagai penyampaian pesan, isi tulisan, saluran, atau media dan pembaca (Dalman, 2016: 3).

Menurut Hartig (dalam Tarigan, 2013: 25-26) menyatakan tujuan penulisan sebagai berikut:

\section{a). Tujuan Penugasan}

Tujuan penugasan ini sebenarnya tidak mempunyai tujuan sama sekali. Penulis menulis sesuatu karena ditugaskan, bukan atas kemauan sendiri (misalnya para siswa yang diberi tugas merangkum buku, sekretaris yang ditugaskan membuat laporan atau notulen rapat).

b). Tujuan Altruistik

Penulis bertujuan untuk menyenangkan para pembaca, menghindarkan kedukaan para pembaca, ingin menolong para pembaca, ingin menolong pembaca memahami, menghargai perasaan, dan penalarannya, ingin membuat hidup para pembaca lebih mudah dan lebih menyenangkan dengan karyanya itu.

c). Tujuan Persuasif

Tulisan yang bertujuan meyakinkan para pembaca akan kebenaran gagasan yang diutarakan. Jenis tulisan persuasif juga banyak di temukan dalam tulisan iklan atau produk untuk menarik konsumen agar produk yang ditawarkan tersebut laris di pasaran.

d). Tujuan Informasional

Tulisan yang bertujuan memberi informasi atau keterangan/penerangan kepada para pembaca.

e). Tujuan Pernyataan Diri

Tulisan yang bertujuan memperkenalkan atau menyatakan diri sang pengarang kepada pembaca.

f). Tujuan Kreatif
Tujuan ini erat hubungannya dengan tujuan pernyataan diri. Tetapi keinginan kreatif di sini melebihi pernyataan diri, dan melibatkan dirinya dengan keinginan mencapai norma artistik, atau seni yang ideal, seni idaman.

g). Tujuan Pemecahan Masalah

Dalam tulisan seperti ini penulis ingin memecahkan masalah yang dihadapi. Penulis ingin menjelaskan, menjernihkan, menjelajahi serta meneliti secara cermat pikiran-pikiran dan gagasan-gagasannya sendiri agar dapat dimengerti dan diterima oleh para pembaca.

Menurut Suparno (dalam Said, 2017: 7-9) menyatakan beberapa manfaat menulis, yaitu sebagai berikut:

1. Menulis dapat Mengembangkan Daya Inisiatif dan Kreatif.

2. Menulis dapat Menyumbang Kecerdasan.

3. Menulis dapat Menumbuhkan Keberanian dan Rasa Percaya Diri.

Menurut Akhadiah, dkk (dalam Said, 2017: 15-18) menyatakan tahap-tahap menulis terdiri atas tiga tahap sebagai berikut:

1. Tahap Prapenulisan

Tahap prapenulisan merupakan fase persiapan menulis, sama halnya dengan pemanasan bagi orang yang berolahraga. Pada fase ini terdapat beberapa hal penting, yaitu memilih topik, menetapkan tujuan dan sasaran, mengumpulkan bahan informasi yang diperlukan, serta mengorganisasikan ide atau gagasan dalam bentuk kerangka karangan.

2. Tahap Penulisan

Saat selesai semua hal yang terdapat pada tahap prapenulisan berarti telah siap untuk menulis. Mengembangkan butir demi butir ide yang terdapat dalam kerangka, dengan memanfaatkan bahan atau informasi yang telah dipilih dan dikumpulkan.

3. Tahap Pascapenulisan

Tahap ini merupakan fase penghalusan dan penyempurnaan tulisan yang dihasilkan. Kegiatan tersebut terdiri atas penyutingan dan perbaikan (revissi).

Menurut Kosasih (2014: 260) menyatakan bahwa iklan merupakan jenis teks yang mengkomunikasikan suatu pesan, gagasan, ataupun pikiran kepada orang lain dan cenderung bersifat persuasif. 
Menurut Kosasih (2014: 261) berdasarkan fungsinya iklan terbagi menjadi dua yaitu:

1). Fungsi informasi, iklan memberitahukan kepada konsumen tentang karakteristik dan manfaat suatu produk.

2). Fungsi transformasional, iklan berusaha untuk mengubah sikap-sikap yang dimiliki oleh konsumen terhadap merek, pola-pola belanja, gaya hidup, teknikteknik mencapai sukses dan sebagainya.

Adapun jenis iklan berdasarkan medianya sebagai berikut:

a. Iklan Media Cetak

Iklan di media cetak memiliki beberapa macam berdasarkan keluasan ruang atau space-nya.

1. Iklan baris adalah iklan yang pemasangannya berupa baris-baris.

2. Iklan kolom adalah iklan yang pemasangannya dalam media berupa kolom-kolom. Disamping menggunakan teks, iklan ini sering pula menyertakan gambar dan berbagai ilustrasi menarik lainnya (Kosasih, 2017: 42).

b. Iklan Elektonik

Menurut Kosasih (2014: 269) iklan elekronik terbagi menjadi lima yaitu:

1. Iklan Radio

Iklan ini hanya mengandalkan efek suara, baik berupa tuturan, musik, bunyi-bunyi, dan sejenisnya. Iklan radio terdiri dari beberapa jenis yaitu:

a) Ad lib, disampaikan oleh penyair secara langsung, berupa kata-kata saja. Biasanya durasi tidak lebih 60 detik.

b) Spot, disampaikan dengan teknik perekaman sehingga membutuhkan persiapan naskah terlebih dahulu. Durasinya berkisar antara 15 sampai dengan 60 detik.

c) Spronsor Program, pemberian waktu khusus kepada sponsor untuk menyampaikan pesan dengan cara membiayai sebuah program acara tertentu.

2. Iklan Televisi

Iklan ini mengandung unsur suara, gambar, dan gerak. Berdasarkan bentuknya iklan televisi dapat dikelompokkan dalam beberapa jenis yaitu:

a) Live action, berupa video klip yang melibatkan unsur gambar, suara, dan gerak secara bersama-sama. b) Animation, iklan berupa gambargambar kartun.

c) Stop action, iklan berupa perpaduan live action dengan teknik animasi.

d) Music, disampaikan melalui musik sebagai kekuatan utama penyampai pesannya.

e) Superimposed, iklan yang dimunculkan diujung layar bersamaan dengan berlangsungnya acara utama.

f) Spronsor program, pihak pengiklan atau sponsor yang membiayai program acara televisi tertentu. Sebagai imbalannya ia dapat menyampaikan pesan iklan dengan lebih dominan.

g) Runing text, iklan yang muncul secara perlahan-lahan berupa teks, biasanya bergerak dari kanan lalu menghilang pada sebelah kiri layar.

h) Backdrop, iklan yang diperlihatkan pada latar belakang suatu acara.

i) Credit title, iklan yang diperlihatkan pada bagian akhir suatu acara.

j) Ad lib, iklan yang disampaikan penyiar secara langsung, baik itu di antara satu acara dengan acara yang lain ataupun dalam program acara tertentu.

k) Property endorsement, iklan yang diperlihatkan melalui properti siaran atau pun pada kostum yang dikenakan oleh artis atau penyiar.

1) Promo ad, iklan oleh pengelola televisi untuk mempromosikan acara-acaranya. Harapannya, pemirsa tertarik menonton acara yang ditayangkan sehingga program acara tersebut mendapatkan jumlah pemirsa yang cukup banyak.

3. Iklan Film

Iklan film yang tersaji dalam judul film (produk sinema). Biasanya muncul sebelum film utama diputar.

4. Iklan Media Digital Interaktif (Internet)

Iklan ini muncul melalui cara-cara yang cukup berbeda dengan iklan-iklan konvensional.Jenis-jenis iklan ini sebagai berikut:

a) Website, iklan ini secara keseluruhan berbentuk website. Seluruh fitur dalam situs itu berupa iklan. Kadang-kadang sebuah perusahaan menjadikan keseluruhan situs itu berupa iklan. Kadang-kadang sebuah perusahaan menjadikan keseluruhan situs perusahaan mereka sebagai iklan. 
b) Banner dan tombol, berupa billboard mini yang tersebar pada sebuah halaman web. Sementara itu, tombolnya pun seringkali berbentuk seperti ikon. Apabila disentuh, tombol itu akanmembawa kita pada situs dari pengiklan atau halaman tambahan baru.

c) Sponsorship, pada iklan ini pihak sponsor tentu membiayai penuh seluruh halaman dari pembuat situs.

d) Search engine marketing, iklan ini muncul saat kita melakukan suatu pencarian data.

e) Classified ads, iklan ini berbentuk seperti iklan baris dalam koran dan biasanya gratis.

f) E-mail advertising, iklan ini dikirimkan melalui e-mail pada para pelanggan yang memang memintanya.

5. Iklan Luar Ruang

Adapun jenis iklan ini sebagai berikut:

1). Iklan outdoor standar, iklan ini berupa baliho dengan berbagai ukuran. Bentuknya mungkin berupa gambar dua dimensi cetak ataupun tiga dimensi.

2). Iklan transit, iklan ini terpasang pada kendaraan umum, terminal, stasiun, dan tempat-tempat umum lainnya. Menurut isinya, iklan ini diklasifikasikan dalam tiga jenis, yakni sebagai berikut:

a. Iklan Pemberitahuan

Iklan ini lebih terfokus pada kepentingan untuk memberitahu khalayak mengenai suatu hal, baik itu berupa peristiwa, keadaan, atau hal lainnya. Iklan jenis ini umumnya dipasang oleh perorangan atau suatu keluarga. Namun adapula yang dipasang oleh perusahaan, misalnya yang berupa pemberitahuan rapat pemegang saham.

b. Iklan Layanan Masyarakat

Iklan ini bertujuan untuk memberikan penerangan atau penjelasan kepada masyarakat. Contohnya, iklan keluarga, berencana dan iklan bahaya narkotik. Pengguna iklan ini umumnya pemerintah dan lembaga swadaya masyarakat (LSM).

c. Iklan Penawaran

Iklan ini bertujuan untuk menawarkan produk atau jasa. Iklan penawaran jasa, pada umumnya dalam bentuk iklan niaga dan iklan lowongan kerja (Kosasih, 2017: 43-45).
Kosasih (2017: 46) menyatakan bahwa struktur teks iklan terdiri atas dua bagian yaitu:

a. Pengenalan produk. Bagian dapat pula disebut sebagai judul teks.

b. Pernyataan persuasif, berisi pernyataan yang mendorong pembaca atau pendengar berbuat sesuatu. Bagian ini biasanya berupa pernyataan tentang kelebihan produk yang ditawarkan.

Kosasih (2017: 46) menyatakan bahwa unsur-unsur iklan terdiri atas beberapa bagian yaitu:

a. Nama produk. Biasanya pada sebuah iklan pasti tertera nama produk yang ditawarkan. Nama produk sebagai informasi mengenai identitas dari produk atau jasa yang kita tawarkan.

b. Gambar produk. Gambar produk pada sebuah iklan menampilkan produk barang atau jasa yang ditawarkan.

c. Kalimat iklan. Pada umumnya kalimat dan meyakinkan calon pengguna barang atau jasa. Tulisan yang ada pada kalimat iklan mudah terlihat, singkat, padat, jelas, efektif dan sebagai penjelasan dari produk yang ditawarkan.

d. Keunggulan produk. Keunggulan dari sebuah produk juga harus dijelaskan di dalam iklan.

e. Harga produk. Biasanya harga produk juga disertakan dalam iklan tersebut agar para pembaca sudah mengetahui harga dari produk atau jasa yang ditawarkan melalui iklan yang dipasang.

f. Nomor telepon pengiklan. Dalam iklan biasanya juga tertera nomor telepon dari penjual agar calon pembeli dapat menghubungi langsung si penjual ketika tertarik untuk membeli produk atau jasa yang ditawarkan pada iklan tersebut.

g. Alamat pengiklan. Dalam sebuah iklan tertera alamat. Biasanya alamat ini berisi informasi mengenai lokasi dari produk yang diperjual belikan agar calon pembeli ingin membeli produk yang ditawarkan tersebut dapat langsung mendatangi alamat yang tertera pada iklan yang dipasang. Menurut Kosasih (2017: 47-48), menyatakan bahwa teks iklan bertujuan untuk menawarkan produk, baik berupa 
barang maupun jasa. Oleh karena itu, katakata yang muncul umumnya bersifat persuasif, bujukan, atau dorongan tentang suatu kebiasaan ataupun gaya hidup.

Pernyataan-pernyataan dalam teks iklan umumnya imperatif, yakni permintaan, ajakan, dorongan, atau larangan. Adapun kalimat imperatif itu sendiri ditandai oleh kata-kata seperti temukan. Kata lainnya adalah ikutilah, hadirilah, wujudkan, nyatakan, nikmati, sebaiknya, marilah, ayo, dan janganlah.

Bahasa iklan sering kali menggunakan bahasa sederhana, mudah diingat, dan mudah pula dipahami. Kalimat yang panjang dan berbelit-belit selalu dihindari dalam iklan. Justru bahasa yang akrab ditengah-tengah khalayak itulah yang sering digunakan disamping memberikan kesan positif tentang produk yang ditawarkan. Disamping itu, bahasa iklan harus singkat sehingga mudah diingat oleh khalayak.

Adapun langkah-langkah menulis iklan yaitu:

a. Mulailah iklan dengan pernyataan yang menarik perhatikan khalayak, yakni berfokus pada kepentingan atau masalah yang mereka hadapi. Misalnya, jika kamu bermaksud menjual obat (jerawat), gunakanlah pernyataan seperti berikut, "Wajah Anda berjerawat?".

b. Penawaran solusi

Misalnya, untuk masalah jerawat, kamu dapat menunjukan kalimat tawaran seperti berikut: 'Ramuan 'Jamu Cantik' mengurangi dan melenyapkan jerawat dalam waktu tiga puluh hari dan Anda kembali tampil cantik".

c. Penunjukan bukti

Yang diperlukan khalayak sesungguhnya adalah bukti. Dalam membuat iklan kamu tidak boleh hanya menyampaikan janji-janji. Agar mereka lebih yakin, tunjukan bukti bahwa solusi yang kamu berikan benar dan sesuai dengan harapan mereka. Misalnya, jerawat Anda akan sembuh dalam 30 hari atau uang kembali. Ada 11.500 orang yang wajahnya kembali putih berseri setelah menggunakan produk kami ini.

d. Mengajukan harga

Misalnya, "Jika Anda ingin merawat wajah Anda sekarang, pesanlah segera ramuan istimewa kamu dengan harga (Kosasih, 2017: 52 - 53).

Pembelajaran menulis iklan termuat dalam materi pembelajaran di SMP Negeri 1 Lawa pada siswa kelas VIII. Materi pembelajaran menulis iklan termuat dalam buku guru dan buku siswa mengacu pada silabus dan mengikuti kurikulum 2013 yang diterbitkan oleh Depdiknas. Pembelajaran menulis iklan tercantum dalam silabus dengan kompetensi dasar 3.4 Menelaah pola penyajian dan kebahasaan teks iklan, slogan atau poster (yang membuat bangga dan memotivasi) dari berbaga isumber yang dibaca dan didengar dan kompetensi dasar 4.4 Menyajikan gagasan, pesan,dan ajakan dalam bentuk iklan, slogan, atau poster secara lisan dan tulis. Setelah mempelajari kaidah kebahasaan teks iklan, siswa dinyatakan menguasai materi jika mampu mencapai kompetesni dasar menyajikan gagasan, pesan, dan ajakan dalam bentuk iklan, slogan, atau poster secara lisan dan tulis.

Jenis penelitian ini merupakan penelitian kelas karena peneliti terlibat langsung di SMP Negeri 1 Lawa khususnya kelas VIII sebagai tempat untuk memperoleh data penelitian.

Metode yang dilakukan dalam penelitian ini adalah metode deskriptif kuantitatif yaitu menyajikan data-data yang ditemukan di lapangan yang berhubungan dengan kemampuan menulis iklan penawaran siswa kelas VIII SMP Negeri 1 Lawa yang selanjutnya diuraikan menggunakan angka-angka dengan prinsip statistik.

Populasi penelitian ini adalah keseluruhan siswa kelas VIII SMP Negeri 1 Lawa. Sesuai data yang diperoleh pada observasi awal, siswa kelas VIII SMP Negeri 1 Lawa tahun ajaran 2019/2020 berjumlah 144 yang tersebar dalam lima kelas, yaitu kelas $\mathrm{VIII}^{1}, \mathrm{VIII}^{2}, \mathrm{VIII}^{3}, \mathrm{VIII}^{4}$, dan VIII $^{5}$

Teknik yang digunakan dalam pengambilan sampel pada penelitian ini adalah stratified proposional random sampling yaitu pengambilan sampel dengan cara merangking prestasi siswa dari yang terendah sampai yang tertinggi berdasarkan nilai ujian semester 2 (dua) kelas VII. Teknik ini digunakan bila populasi 
mempunyai anggota/unsur yang bersifat heterogen dan berstrata secara proposional. Instrumen yang digunakan dalam penelitian ini adalah tes kemampuan menulis, yaitu kemampuan menulis iklan penawaran berdasarkan unsur-unsur iklan yaitu nama produk, gambar produk, kalimat iklan, keunggulan produk, harga produk, nomor telepon pengiklan, dan alamat pengiklan yang temuat dalam lembar kerja siswa. Kegiatan menulis dilakukan agar siswa dapat kreatif dan produktif dalam menulis. Waktu yang disediakan untuk menyusun iklan selama 2 x 40 menit (2 jam pelajaran).

Teknik pengumpulan data dalam penelitian ini, dilakukan dengan teknik tes yaitu memberikan instrument soal kepada siswa selanjutnya siswa menulis iklan penawaran berdasarkan jenis barang/jasa yang akan ditawarkan dengan memperhatikan nama produk, gambar produk, kalimat iklan, keunggulan produk, harga produk, nomor telepon pengiklan, dan alamat pengiklan dalam instrumen. Untuk memperlancar dan menjaga objektivitas pengumpulan data, peneliti akan dibantu oleh guru mata pelajaran bahasa Indonesia kelas VIII SMP Negeri 1 Lawa agar siswa berada dalam keadaan yang wajar atau dalam keadaan yang tidak terbebani oleh adanya peneliti.

Teks penilaian tulisan berupa teks iklan yang ditulis oleh siswa berdasarkan jenis barang/jasa yang akan ditawarkan. Hasil kerja siswa dinilai dengan beberapa kriteria penilaian yaitu aspek sebagai berikut:nama produk, gambar produk, kalimat iklan, keunggulan produk, harga produk, nomor telepon pengiklan, dan alamat pengiklan.

Analisis data dilakukan dengan teknik persentase dengan menggunakan angka-angka. Teknik persentase digunakan untuk mengetahui kemampuan siswa dalam menulis iklan penawaran. Tingkat kemampuan dalam menulis iklan penawaran mengacu pada kemampuan yaitu anggapan bahwa secara individual maupun klasikal dikatakan mampu/tuntas apabila dapat menguasai minimal $70 \%$ dari aspek yang dinilai secara individual, sedangkan klasikal dikatakan mampu/tuntas apabila dapat menguasai $85 \%$ dari aspek yang dinilai secara klasikal. Standar kelulusan atau siswa dikatakan mampu apabila siswa memperoleh standar KKM $70 \%$.

\section{Pembahasan}

Berdasarkan hasil analisis data, ditemukan perolehan skor keseluruhan bedasarkan tes Kemampuan Menulis Iklan Penawaran Siswa Kelas VIII SMP Negeri 1 Lawa, sebagaimana ditampilkan dalam tabel berikut:

Persentase Keseluruhan Aspek Penilaian

Kemampuan Menulis Iklan Penawaran

Siswa Kelas VIII SMP Negeri 1 Lawa

Tabel 2.1

\begin{tabular}{cccc}
\hline No & $\begin{array}{c}\text { Kategor } \\
\text { i }\end{array}$ & Frekuensi & $\begin{array}{c}\text { Persenta } \\
\text { se }\end{array}$ \\
\hline 1 & Mampu & 58 & $55,23 \%$ \\
\hline 2 & Tidak & 47 & $44,76 \%$ \\
& Mampu & & \\
\hline & Jumlah & 105 & $100 \%$ \\
\hline
\end{tabular}

Berdasarkan tabel di atas, dapat diperoleh data bahwa dari siswa yang dijadikan sampel terdapat 58 siswa $(55,23 \%)$ memperoleh kategori mampu, 47 siswa $(44,76)$ yang tergolong tidak mampu.

Dengan demikian, kemampuan menulis iklan penawaran siswa kelas VIII SMP Negeri 1 Lawa dikategorikan tidak mampu secara klasikal. Dikatakan tidak mampu karena kemampuan siswa dalam menulis iklan penawaran secara keseluruhan tidak mencapai $85 \%$ standar kemampuan secara keseluruhan yang ditetapkan. Siswa dikatakan mampu/tuntas secara keseluruhan bila rata-rata siswa yang memperoleh nilai di atas Kriteria Ketuntasan Minimal (70) mencapai $85 \%$.

Adapun gambaran deskripsi kemampuan menulis iklan penawaran Siswa Kelas VIII SMP Negeri 1 Lawa pada Setiap Aspek berdasarkan hasil tes sebagai berikut:

Persentase Kemampuan Menulis Iklan Penawaran Siswa Kelas VIII SMP Negeri 1 Lawa pada Aspek Nama Produk Tabel 2.2

\begin{tabular}{|c|c|c|c|}
\hline No & Kategori & Frekuensi & $\begin{array}{c}\text { Persentase } \\
(\%)\end{array}$ \\
\hline 1 & Mampu & 105 & $100 \%$ \\
\hline 2 & $\begin{array}{c}\text { Tidak } \\
\text { Mampu }\end{array}$ & 0 & $0 \%$ \\
\hline & Jumlah & 105 & $100 \%$ \\
\hline
\end{tabular}

381 | Jurnal BASTRA (Bahasa dan Sastra), Vol. 5 No.4, Edisi Oktober 2020/e-ISSN: 2503-3875/http://ojs.ohu.ac.id/index.php/BASTRA 
ditinjau dari aspek nama produk secara klasikal masuk kategori mampu, karena kemampuan siswa mencapai $100 \%$ atau lebih dari batas kemampuan secara klasikal $85 \%$.

Persentase Kemampuan Menulis Iklan Penawaran Siswa Kelas VIII SMP Negeri 1 Lawa pada Aspek Gambar Produk Tabel 2.3

\begin{tabular}{cccc}
\hline No & Kategori & Frekuensi & $\begin{array}{c}\text { Persentase } \\
(\mathbf{\%})\end{array}$ \\
\hline 1 & Mampu & 32 & $30,47 \%$ \\
\hline 2 & Tidak & 73 & $69,52 \%$ \\
& Mampu & & \\
\hline & Jumlah & 105 & $100 \%$ \\
\hline
\end{tabular}

Dengan demikian, bila dilihat dari kemampuan menulis iklan penawaran ditinjau dari aspek gambar produk secara klasikal masuk kategori tidak mampu, karena kemampuan siswa mencapai $30,47 \%$ atau tidak mencapai kemampuan klasikal $85 \%$.

Persentase Kemampuan Menulis Iklan Penawaran Siswa Kelas VIII SMP Negeri 1 Lawa pada Aspek Kalimat Iklan Tabel 2.4

\begin{tabular}{cccc}
\hline No & Kategori & Frekuensi & $\begin{array}{c}\text { Persentase } \\
(\boldsymbol{\%})\end{array}$ \\
\hline 1 & Mampu & 5 & $4,76 \%$ \\
\hline 2 & Tidak & 100 & $95,23 \%$ \\
& Mampu & & \\
\hline & Jumlah & 105 & $100 \%$ \\
\hline
\end{tabular}

Dengan demikian, bila dilihat dari kemampuan menulis iklan penawaran ditinjau dari aspek kalimat iklan secara klasikal masuk kategori tidak mampu, karena kemampuan siswa mencapai 4,76\% atau tidak mencapai kemampuan klasikal $85 \%$.

Persentase Kemampuan Menulis Iklan Penawaran Siswa Kelas VIII SMP Negeri 1

Lawa pada Aspek Keunggulan Produk Tabel 2.5

\begin{tabular}{|c|c|c|c|}
\hline No & Kategori & Frekuensi & $\begin{array}{l}\text { Persent } \\
\text { ase }(\%)\end{array}$ \\
\hline 1 & Mampu & 47 & $44,76 \%$ \\
\hline 2 & $\begin{array}{c}\text { Tidak } \\
\text { Mampu }\end{array}$ & 58 & $55,23 \%$ \\
\hline & Jumlah & 105 & $100 \%$ \\
\hline
\end{tabular}

ditinjau dari aspek keunggulan produk secara klasikal masuk kategori tidak mampu, karena kemampuan siswa mencapai 56,19\% atau tidak mencapai kemampuan klasikal $85 \%$.

Persentase Kemampuan Menulis

Iklan Penawaran Siswa Kelas VIII SMP

Negeri 1 Lawa pada Aspek Harga Produk Tabel 2.6

\begin{tabular}{cccc}
\hline No & Kategori & Frekuensi & $\begin{array}{c}\text { Persentase } \\
(\mathbf{\%})\end{array}$ \\
\hline 1 & Mampu & 98 & $93,33 \%$ \\
\hline 2 & $\begin{array}{c}\text { Tidak } \\
\text { Mampu }\end{array}$ & 7 & $6,66 \%$ \\
& & \\
\hline & Jumlah & 105 & $100 \%$ \\
\hline & Dengan demikian, bila dilihat dari
\end{tabular}
kemampuan menulis iklan penawaran ditinjau dari aspek harga produk secara klasikal masuk kategori mampu karena kemampuan siswa mencapai 93,33\% atau lebih dari batas kemampuan siswa secara klasikal $85 \%$.

Persentase Kemampuan Menulis Iklan Penawaran Siswa Kelas VIII SMP Negeri 1 Lawa pada Aspek Nomor Telepon Pengiklan Tabel 2.7

\begin{tabular}{cccc}
\hline No & Kategori & Frekuensi & $\begin{array}{c}\text { Persentase } \\
(\boldsymbol{\%})\end{array}$ \\
\hline 1 & Mampu & 100 & $95,23 \%$ \\
\hline 2 & $\begin{array}{c}\text { Tidak } \\
\text { Mampu }\end{array}$ & 5 & $4,76 \%$ \\
\hline & Jumlah & 105 & $100 \%$ \\
\hline
\end{tabular}

Dengan demikian, bila dilihat dari kemampuan menulis iklan penawaran ditinjau dari aspek nomor telepon pengiklan secara klasikal masuk kategori mampu, karena kemampuan siswa mencapai 95,23\% atau lebih dari batas kemampuan siswa secara klasikal $85 \%$.

Persentase Kemampuan Menulis Iklan Penawaran Siswa Kelas VIII SMP Negeri 1 Lawa pada Aspek Alamat Pengiklan Tabel 2.8

\begin{tabular}{cccc}
\hline No & Kategori & Frekuensi & $\begin{array}{c}\text { Persentase } \\
(\boldsymbol{\%})\end{array}$ \\
\hline 1 & Mampu & 100 & $95,23 \%$ \\
\hline 2 & Tidak & 5 & $4,76 \%$ \\
& Mampu & & \\
\hline & Jumlah & 105 & $100 \%$ \\
\hline
\end{tabular}

382 I Jurnal BASTRA (Bahasa dan Sastra), Vol. 5 No.4, Edisi Oktober 2020/e-ISSN: 2503-3875/http://ojs.ohu.ac.id/index.php/BASTRA 
Dengan demikian, bila dilihat dari kemampuan menulis iklan penawaran ditinjau dari aspek alamat pengiklan secara klasikal masuk kategori mampu, karena kemampuan siswa mencapai 95,23\% atau lebih dari batas kemampuan siswa secara klasikal $85 \%$.

Berdasarkan analisis persentase sebelumnya, dapat dikatakan bahwa kemampuan menulis iklan penawaran siswa kelas VIII SMP Negeri 1 Lawa pada setiap aspek memperlihatkan nilai persentase yang bervariasi untuk lebih jelasnya dapat dilihat pada tabel berikut:

Rangkuman Data Kemampuan Menulis

Iklan Penawaran Siswa Kelas VIII SMP

Negeri 1 Lawa pada Keseluruhan Aspek Tabel 2.9

\begin{tabular}{|c|c|c|c|}
\hline No & $\begin{array}{c}\text { Aspek } \\
\text { Penilaian } \\
\end{array}$ & $\begin{array}{c}\text { Tingkat } \\
\text { Kemampuan }\end{array}$ & Kategori \\
\hline 1 & $\begin{array}{l}\text { Nama } \\
\text { Produk }\end{array}$ & $100 \%$ & Mampu \\
\hline 2 & $\begin{array}{l}\text { Gambar } \\
\text { Produk }\end{array}$ & $30,47 \%$ & $\begin{array}{c}\text { Tidak } \\
\text { Mampu }\end{array}$ \\
\hline 3 & $\begin{array}{l}\text { Kalimat } \\
\text { Iklan }\end{array}$ & $4,76 \%$ & $\begin{array}{c}\text { Tidak } \\
\text { Mampu }\end{array}$ \\
\hline 4 & $\begin{array}{l}\text { Keunggulan } \\
\text { Produk }\end{array}$ & $44,76 \%$ & $\begin{array}{c}\text { Tidak } \\
\text { Mampu }\end{array}$ \\
\hline 5 & $\begin{array}{l}\text { Harga } \\
\text { Produk }\end{array}$ & $93,33 \%$ & Mampu \\
\hline 6 & $\begin{array}{l}\text { Nomor } \\
\text { Telepon } \\
\text { Pengiklan }\end{array}$ & $95,23 \%$ & Mampu \\
\hline 7 & $\begin{array}{l}\text { Alamat } \\
\text { Pengiklan }\end{array}$ & $95,23 \%$ & Mampu \\
\hline \multicolumn{4}{|c|}{$\begin{array}{l}\text { Berdasarkan hasil deskripsi diatas, } \\
\text { diinterprestasikan bahwa dari ketujuh } \\
\text { yang diteliti, aspek nama produk } \\
\text { uduki peringkat tertinggi dengan } \\
\text { ntase kemampuan } 100 \% \text {. diikuti } \\
\text { mpuan pada aspek nomor telepon } \\
\text { kan dengan persentase } 95,23 \% \text {, aspek } \\
\text { at pengiklan dengan persentase } 95,23 \% \text {, } \\
\text { spek harga produk dengan persentase } \\
\% \text {. Kemudian untuk peringkat terendah } \\
\text { pada aspek keunggulan produk dengan } \\
\text { ntase } 44,76 \% \text {, dan diikuti kalimat iklan } \\
\text { an persentase } 4,76 \% \text { dan aspek gambar } \\
\text { k dengan persentase } 30,47 \% \text {. }\end{array}$} \\
\hline
\end{tabular}

\section{Kesimpulan}

Berdasarkan hasil analisis data, dapat disimpulkan bahwa dari 105 siswa yang menjadi sampel penelitian, terdapat 58 siswa $(55,23 \%)$ tergolong mampu menulis iklan penawaran dan 47 siswa $(44,76 \%)$ tergolong tidak mampu dalam menulis iklan penawaran. Dengan demikian dapat dikatakan bahwa siswa kelas VIII SMP Negeri 1 Lawa tidak mampu secara klasikal dalam menulis iklan penawaran dengan persentase kemampuan 55,23\% belum mencapai kriteria ketuntasan klasikal $85 \%$. Hal itu dapat dilihat dari hasil perolehan skor pada ketujuh aspek yang diteliti, kemampuan aspek nama produk dengan persentase $100 \%$, diikuti kemampuan pada aspek gambar produk dengan persentase $30,47 \%$, diikuti kemampuan aspek kalimat iklan dengan persentase 4,76\%. Diikuti kemampuan pada aspek keunggulan produk dengan persentase 44,76\%, diikuti kemampuan pada aspek harga produk dengan persentase $93,33 \%$ dan terakhir kemampuan pada aspek nomor telepon pengiklan dan diikuti kemampuan pada aspek alamat pengiklan dengan persentase $95,23 \%$.

Berdasarkan rumusan simpulan di atas, penulis menyarankan beberapa hal sebagai berikut:

1. Guru bahasa Indonesia perlu memberikan dorongan terhadap siswa agar selalu mempertahanakan kemampuan yang dimiliknya khususnya dalam menulis iklan penawaran.

2. Untuk mempelajari menulis iklan penawaran, guru dapat menyesuaikan ketuntasan materi dengan pemahaman siswa sehingga keseluruhan aspekaspek dalam menulis iklan penawaran dapat di pahami oleh siswa.

3. Sebaiknya dilakukan penelitian lanjutan yang tidak dibicarakan dalam penelitian.

\section{Referensi}

Abigail, Monica. 2015. Belajar Menulis. Surabaya: JP Books.

Ahmad, H.P. dan Alek. 2016. Bahasa Indonesia untuk Perguruan Tinggi. Jakarta: Erlangga.

Dalman. 2016. Keterampilan Menulis. Jakarta: Rajawali Pers.

Kosasih, E. 2014. Jenis-Jenis Teks (Analisis Fungsi, Struktur, dan Kaidah serta Langkah Penulisannya). Bandung: Yrama Widya. 
Kosasih, E. 2017. Bahasa Indonesia Kelas VIII SMP/MTs. Jakarta: Kemendikbud.

Kosasih,E. 2017. Buku Guru Bahasa Indonesia SMP/MTs Kelas VIII. Jakarta: Kemendikbud.

Lukitaningsih, Ambar. 2013. "Iklan yang Efektif Sebagai Strategi Komunikasi Pemasaran". Yogyakarta: Fakultas Ekonomi Universitas Sarjanawiyata Tamansiswa (Online), Vol. 13, No. 2. https://media.neliti.com/publication s/23468-ID-iklan-yang-efektifsebagai-strategi-komunikasipemasaran.pdfdiunduh pada tanggal 12 September 2019.

Parera, Jos. Daniel. 1993. Menulis Tertib dan Sistematik. Jakarta: Penerbit Erlangga.

Rosidi, Imron. 2009. Menulis Siapa Takut. Yogyakarta: Kanisius

Saddhono, Kundharu dan Slamet. 2014. Pembelajaran Keterampilan Berbahasa Indonesia Teori dan Aplikasi. Yogyakarta. Graha Ilmu.

Said, Rahmad. 2017. Penggunaan Bahasa Indonesia yang Benar pada Karya Ilmiah. Kendari: CV. Metro Graphia Kendari.

Sugiyono. 2015. Metode Penelitian Pendidikan (Pendekatan Kuantitatif, Kualitatif, dan R\&D). Bandung: Alfabeta.

Suharma, dkk. 2010. Bahasa dan Sastra Indonesia Kelas IX SMP. Bogor: Yudistira.

Sumardjo, Jakob. 2004. Catatan Kecil Tentang Menulis Cerpen. Yogyakarta: Pustaka

Supriatma, Agus. 2005. Taman Belajar Bahasa dan Sastra Indonesia untuk Kelas IX SMP/MTs. Bandung: Pribumi Mekar.

Suriamiharja, Agus, dkk. 1996. Petunjuk Praktis Menulis. Jakarta: Depdikbud.

Soebachman. 2016. Mahir Menulis dalam 4 Hari. Yogyakarta: Kaum Pustaka.

Tarigan, Henry Guntur. 2013. Menulis

Sebagai Suatu Keterampilan Berbahasa.

Bandung: CV Angkasa. 